\title{
The Catechetical School in Alexandria
}

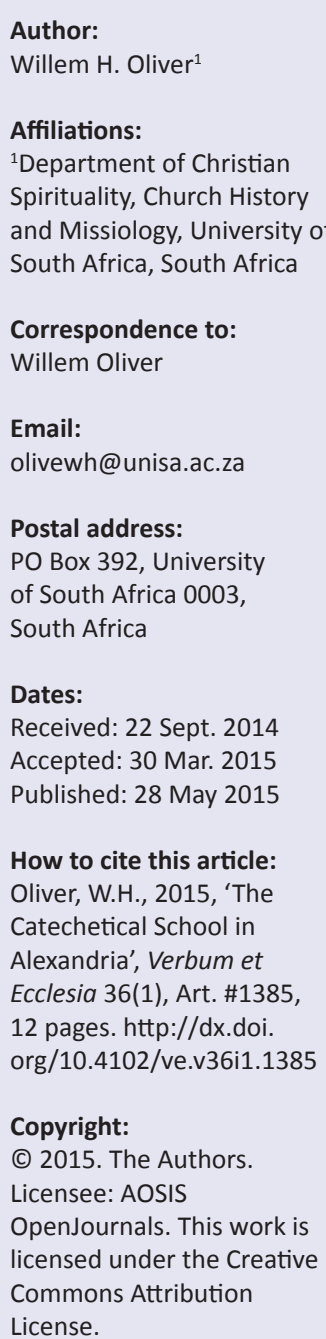

During her Golden Era, Alexandria, the Delta City of Egypt, was the pride of Africa in that she was larger than the two other world cities of the Roman Empire - Rome and Antioch and also the unrivalled intellectual centre of the (Greco-)Roman world. Her schools, including the Didaskaleion - the Catechetical School - outshone the schools of her rivals by far. During the first half of the 1st century CE and specifically after the destruction of the temple and the fall of Jerusalem in $70 \mathrm{CE}$, many Jews fled their home country for different parts of the Roman Empire, like Transjordan, Syria and Africa. A number of these Jews later called Christians - believed in Jesus of Nazareth. In Alexandria, these believers were confronted with different religions, cults and philosophies. The Didaskaleion was founded to rival these religions and cults and to provide the students with the necessary basis for their newly found religion. The lack of literature, on the one hand, and the credibility of the extant literature, on the other, caused great difficulty in reasoning with authority on the Didaskaleion. This is part one of two articles, the second one being constructed around the heads of the School.

Intradisciplinary and/or interdisciplinary implications: Research about Africa done by Africans (inhabitants of Africa) need to increase because, in many ways Africa, is silent or silenced about her past. The fundamental question is: 'Can anything good come out of Africa?' My answer is, 'Yes! Come and see.' Therefore these two articles attempt to indicate the significance of Africa, which was actually the place where Christian Theology was founded. This has intra- as well as interdisciplinary implications. In this case the investigation is done from a theological perspective.

\section{Introduction}

When he created a new Egyptian capital (later called Alexandria) out of the harbour village Rhakotis in 331 BCE (cf. Isichei 1995:13), one of the wisest approaches of Alexander the Great was religious tolerance. With this approach, he permitted the indigenous religion of Egypt to remain intact and allowed both the Greeks with their numerous gods and the Jews (Judaism). After the Roman Province of Egypt was established in 30 BCE, the city of Alexandria flourished for almost 700 years onwards - depicted as the Golden Era of Alexandria. During this time that ended with the Arab invasion in $642 \mathrm{CE}$, she was home to many religions, cults and philosophies, expressing themselves amongst different cultures within the city. The most important of these were the Greek and the Roman cultures, comingling with the local Egyptian culture (cf. Fogarty 2004:14-15). One of the religions was rather new and was an offspring of Judaism. This new religion was without a name when its adherents arrived in Alexandria. They were merely followers of the doctrines of Jesus of Nazareth. ${ }^{1}$ Hatch (1957) refers as follows to the way in which the adherents of this religion went along on a daily basis:

The earliest Christians had been content to believe in God and to worship Him, without endeavouring to define precisely the conception of Him which lay beneath their faith and their worship. They looked up to Him as their Father in heaven. They thought of Him as One, as beneficent, and as supreme. But they drew no fence of words round their idea of Him, and still less did they attempt to demonstrate by processes of reason that their idea of Him was true. (p. 135)

This young religion was soon confronted and infiltrated by philosophy as well as all the other cults and religions in the city, and maybe for the first time, the adherents to this religion were forced to create a belief system for themselves. As Greek philosophy had the way of turning knowledge into speculation (cf. Hatch 1957:137), the young religion had to 'double check' its facts - and they did it in a philosophical way (as discussed below). The necessity of a 'school'

1.Fogarty (2004:101) referred to the earliest Christians as 'believers in Christ's teachings' In this article the earliest Christians are called 'followers of (the doctrines of) Jesus (of Nazareth)'. According to Acts 11:26, these followers were first called 'Christians' in Antioch (in the late 1st century), and it would take some time before they would be called by that name in Alexandria. Therefore, at least in the 1 st century and the first part of the 2 nd century, it would be wrong to refer to them as 'Christians' in Alexandria. 
to teach the basic facts to the newly converted and to guide them to baptism led to the founding of the Catechetical School, called the Didaskaleion.

Alexandria was a world-famous city, especially renowned for her academic excellence, resulting in the founding of schools ('universities') like the Musaion [shrine of the Muses] with its library housing 700000 volumes, as well as the Serapium and the Sebastion, each with a own huge library (Fogarty 2004:14). This could have been the trigger for the followers of the doctrines of Jesus to start with the Didaskaleion. The facts relating to the founding of the School are rather limited and somehow even spurious (cf. Van den Broek 1995:39-47). Nevertheless, there is great significance in researching the School, as summarised by Malaty (1995):

We are in need of studying the thoughts of the School of Alexandria, especially during the period of the first five centuries². It helps us to attain the divine grace of the Holy Trinity and practice the unity with the Father and the Son through the work of the Holy Spirit. It reveals how the early church understands the Holy Scriptures, christianizes the Hellenic culture, and faces heresies. (p. 6)

\section{The Didaskaleion ${ }^{3}$ Was there 'in fact' a Catechetical School in Alexandria?}

Two main lines of thinking can be distinguished concerning this question: scholars with the view that there was no Catechetical School in Alexandria at all, or at least not before Clement or Origen, and scholars who argue positively towards the existence of the School before Clement and Origen. The first view point is held by 'more recent' scholars:

- In her article, Annewies Van den Hoek (1997:59-87) questions the very notion of a Christian School in Alexandria. Although she is against the notion of an institutionalised School, she admits that '... teaching and scholarship within the penumbra of the church was a long-established activity in Alexandria well before Origen' (Van den Hoek 1997:76). She argues further that Eusebius created chains of succession of heads of the School '.. in order to give the organizations of his time an enhanced legitimacy' (Van den Hoek 1997:61). She (Van den Hoek 1997:76) then continued: 'In general, Eusebius's measured comments on the Alexandrian succession and school are verifiable, right down to the ambiguity of its terminology.'

- Jutta Tloka (2006:112-124) also questions the existence of a School as she points out that Eusebius himself used different expressions when referring to the School during the times of Pantaenus and Clement.

- Anthony Grafton and Megan Williams (2006:78) acknowledge the fact that there could have been be a School, but they point out that the term $\delta 1 \delta \alpha \sigma \kappa \alpha \lambda \varepsilon$ ĩov

\footnotetext{
2.In fact, it should only be four centuries because the last 'head' of the School was Rhodon by the end of the 4 th century (In a next, related article, under review with Vetus Testamentum, I plan on addressing this matter further.)

3.In this article, two terms will mostly be used to refer to the Catechetical School in Alexandria, namely 'Didaskaleion' and 'School'.
}

initially referred to an institution that functioned independently without much structure and that it did not depend on the bishop of Alexandria for starters. Even Origen had to rely on financial support from Ambrose as the Bishop did not remunerate him.

- According to Roelof Van den Broek, Eusebius did not work with facts when he pinned down his thoughts on the Didaskaleion. He actually worked on hearsay as he stated it himself in his Hist. Eccl. 5.10: 'This school has lasted on to our time, and we have heard [my emphasis - WO] that it is managed by men powerful in their learning and zeal for divine things.' Van den Broek (1995:43) assumes that, in the 2nd-century Alexandrian Christianity, teachers were merely laymen even though they were responsible for '... all forms of religious education, from pre-baptismal instruction to high theology'. He refers to them as '...

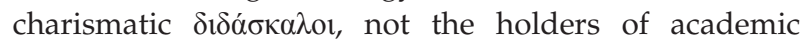
chairs, incorporated in a school with a fixed curriculum' (Van den Broek 1995:43). This, amongst others, leads him to conclude that there was '... no school, in the sense of a Christian academy, with a regular teaching programme' (Van den Broek 1995:43). His argument refers to the existence of the School before the 3rd century because he admits that the second decade of the 3rd century marked the existence of a Christian School at Alexandria. Even then, the Didaskaleion would not be a '... catechetical institute, housed in a separate building possessed by the church,' and the teacher would remain a lay teacher 'who received his students at home' (Van den Broek 1995:44).

- Clemens Scholten refers to the writings of Eusebius and Clement, postulating that they differed from each other in reference to the School in Alexandria. This meant that there was '... keine Einigkeit in der Interpretation dieser Quellen und damit über den eigentlichen Charakter der alexandrinischen Katechetenschule und ihre Aufgabe und Stellung in der dortige Kirche' ['no consensus in the interpretation of these sources and thus on the very character of the Alexandrian Catechetical School and her role and position in the local church (author's own translation)] during that time (Scholten 1995:17). He concludes his article by stating that the term (designation) 'Catechetical School' should not be applied to the School in Alexandria because it would create a misunderstanding (Scholten 1995:37). The School was no place for the instruction of catechumens but a '... theologische Hochschule der dortigen Kirche' [a theological college of the church there (author's own translation)] (Scholten 1995:37), presenting the Quadrivium and Philosophy especially during the time of Origen.

- Ilaria Ramelli (2009) in her article also mentions Emanuela Prinzivalli who postulates that there were private schools during the times of Pantaenus and Clement. From Origen onward, one could talk of a public School because, by then, the church in Alexandria had already associated itself with didactic activities (Prinzivalli 2003:911-937).

Cognisance is taken of the fact that we do not have exact evidence concerning the existence of the Didaskaleion in 
Alexandria, especially before Clement or Origen. We are also aware of the fact that Eusebius did not work with cold facts but with interpreted information. Yet today, Eusebius' Historia Ecclesiastica is still the primary source on this subject although his is (to a certain extent) an unreliable reconstruction based on sketchy evidence and distorted for his own purposes. Nevertheless, it is impossible to ignore Eusebius, and therefore, his writings will be utilised here though with this caution in mind.

Lastly, should we agree to the fact that there was a Didaskaleion in Alexandria, cognisance must be taken of the fact that there were other Christian teachers in the Delta City like Basilides and his son Isidore - during the first quarter of the 2nd century - and Carpocrates and his disciples during the middle of the 2 nd century (cf. Löhr 2010:171).

\section{The use of the term $\delta \mathbf{1} \delta \alpha \sigma \kappa \alpha \lambda \varepsilon i 0 v$ and related terms}

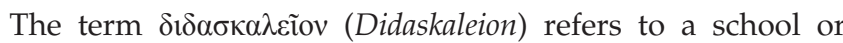
place of learning (perhaps initially a house). In many passages in Eusebius, the term had this meaning. This term can, however, also refer to (divine) teaching or doctrine as such (although not used in that sense in this article) as it is found in Eusebius' Hist. Eccl. 6.21.4:

She [Julia Mamaea, the mother of the Emperor Alexander Severus] was then staying in Antioch and had him [Origen] sent for with a military escort. After spending some time with her and pointing out to her a great many things that were to the glory of the Lord and that had to do with the excellence of the divine teaching ( $\delta l \delta \alpha \sigma \kappa \alpha \lambda \varepsilon \tilde{i} o v)$, he hastened back to his customary studies.

Eusebius did not only use the term $\delta 1 \delta \alpha \sigma \kappa \alpha \lambda \varepsilon i ̃ o v$ to refer to the School. Van den Hoek (1997:74-75) named quite a few other variations by which Eusebius referred to the School and concluded that this flexible vocabulary could indicate that there was no fixed term for the School:

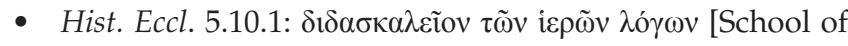
the sacred words]

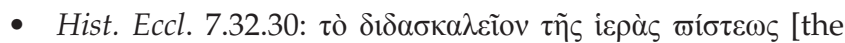
School of the sacred faith]

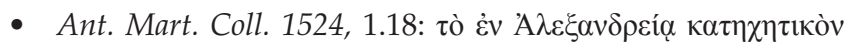
$\delta 1 \delta \alpha \sigma \kappa \alpha \lambda \varepsilon i \tilde{o v}$ [the Catechetical School in Alexandria]

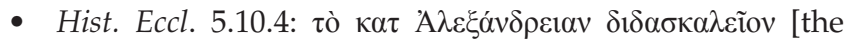
School in Alexandria]

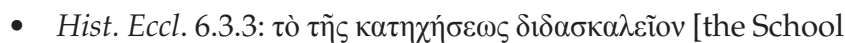
of instruction]

- Hist. Eccl. 6.29.4: $\dot{\eta} \delta 1 \alpha \tau \rho \iota \grave{\eta} \tau \tilde{\eta} \varsigma \chi \alpha \tau \eta \chi \eta ் \varepsilon \omega \varsigma$ [the School of instruction]

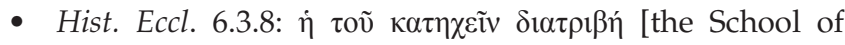
instruction]

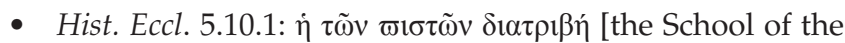
faithful]

- Hist. Eccl. 6.3.1, 6.4.3: $\dot{\eta} \delta 1 \alpha \tau \rho ı ß \eta$ [the School]

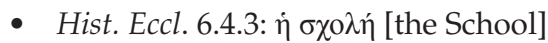

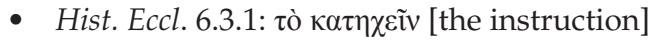

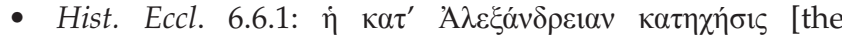
instruction in Alexandria]

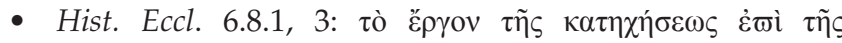
A $\lambda \varepsilon \xi \alpha v \delta \rho \varepsilon i ́ \alpha \varsigma$ [the work of instruction in Alexandria]

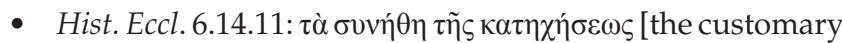
activities of instruction].

Clement and Origen, the two famous heads of the School, refrained from using the term $\delta i \delta \alpha \sigma \kappa \alpha \lambda \varepsilon \tilde{i}_{0} v$ in their writings as, in their time, it could also refer to a heretical religious group, with which they did not want to be associated (cf. Van den Hoek 1997:74). This could also be the reason why

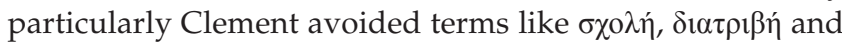

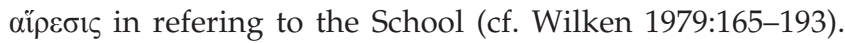
Origen also decided against the use of the term $\delta 1 \delta \alpha \sigma \kappa \alpha \lambda \varepsilon i v^{\circ}$ when referring to his own teaching, at least in the works for which the Greek text has survived. Only once did he use the term when referring to the '... venerable school of the Pythagoreans' (Cont. Cels. 3.51).

\section{Founding and development of the School Background}

Educational background: As Alexandria in her Golden Era was the metropolis of Egypt, she was, amongst others, the flourishing seat of commerce. Having the greatest library in the ancient world, she could therefore be established as one of the greatest centres of learning in the Roman Empire.

Apart from the mentioned Musaion, Serapium and Sebastion, there was also a Christian Scriptorium in the city, established in the middle of the 2nd century. This Scriptorium was related to the Christian library, and it preserved, enlarged and disseminated the collection of the library. The Scriptorium already managed the textual transmission of scholars like Philo as well as the epistles of Paul and other early Christian writings which can be traced back to 2nd-century Alexandria. The Scriptorium, being the source of collating, editing and copying texts, must have had links with the Didaskaleion (Van den Hoek 1997:82), producing ' ... biblical texts, established by the methods of textual criticism which had been developed by much earlier Alexandrian scholars for the edition of Greek literary texts' (Van den Broek 1996:201). There also existed a '... circle of biblical scholars, Christian $\gamma \rho \alpha \mu \mu \alpha \tau$ เoí, and well-educated

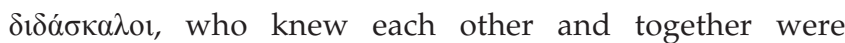
engaged in integrating their Christian belief into the Greek culture they also believed in' (Van den Broek 1996:201-202). Not much is known about these two institutions, leading one to the conclusion that they were established for the local Christians and therefore did not have the ecumenical character that was one of the characteristics that made famous the Didaskaleion. This environment created the impetus and formed the breeding ground for the founding of a Christian School. The School was advertised abroad and attracted large numbers of students from the Mediterranean world. One of the determinants for students coming to Alexandria was the abovementioned Musaion which was the most famous school in the East. The Catechetical School 
in Alexandria was the first of its kind concerning theological studies in Christian antiquity.

Religious and philosophical background: Despite the educational background of Alexandria, the first centuries of the Common Era were a time of great transition and unrest. It was a period in which the values by which the ancient world had lived were steadily being uprooted. By the middle of the 2nd century, as Tripolitis (1985) points out, the situation was as follows:

\begin{abstract}
... the Roman Empire was witnessing a succession of barbarian invasions, bloody civil wars, various recurring plagues, famines and economic crises. Moreover, the cosmopolitanism of the Empire, the fusion of races, customs, cultures and religions was gradually destroying the State religion, which had served as the basis of the political, social and intellectual life. This period, which began in the early part of the second century, was one of general material and moral insecurity. (p. 9)
\end{abstract}

This period also marked the increased popularity of the old mysteries of Samothrace and Eleusis. Together with all the mysteries, cults and religions, philosophy attempted to offer a solution to the spiritual needs of the masses during these trying times. As the scepticism of the Epicureans and the ascetic ideals of the Stoics influenced the lives of the intellectuals for over four centuries, they started to embrace Platonism again because they felt that the writings of Plato could satisfy their spiritual needs. This marked the beginning of a new Platonism '... which had absorbed many of the ideas of Aristotle, the Stoics and the neo-Pythagoreans' (Tripolitis 1985:10) and had an influence on the thoughts of various philosophical and religious movements of the time. It culminated in a philosophical movement called Middle Platonism during the second part of the 2nd century. According to Middle Platonism, mankind had one object, namely to free itself from the material world and return to the Divine. The influence of philosophy on the School will be discussed later in this article.

\section{The founding of the School}

The exact founding date of the Didaskaleion in Alexandria is uncertain. Malaty (1995:208) has the view that the School was established early in the 5 th decade CE by Mark. His source for that is the Hist. Eccl. 2.16 where Eusebius mentions that Mark visited Alexandria and preached there. This could at least be a starting point for an informal school - the 'early beginnings' of a (house) school by the middle of the 1st century CE. It would then be an allusion to Eusebius' Hist. Eccl. 5.10 where he refers to the School as 'of old a school of sacred learning' but without mentioning a specific date.

Schaff (1885a) refers as follows to the spread of earliest Christianity as background to the founding of the School:

From Britain to the Ganges it [Christianity] had already made its mark. In all its Oriental identity, we have found it vigorous in Gaul and penetrating to other regions of the West. From its primitive base on the Orontes, it has extended itself to the deltas of the Nile; and the Alexandria of Apollos and of St. Mark has become the earliest seat of Christian learning. There, already, have the catechetical schools gathered the finest intellectual trophies of the Cross; and under the aliment of its library springs up something like a Christian university. (p. 369)

In his Hist. Eccl. 6.6.1, Eusebius refers to the Didaskaleion as an existing institution: 'Clement, who succeeded Pantaenus, was head of the catechetical instruction (Didaskaleion) at Alexandria up to such a time that Origen also was one of his students.' This passage mentions Pantaenus (who died early in the 3rd century) as one of the heads of the School without stating that he was the first head. This passage has led scholars like Fogarty (2004:29) to conclude that the School started during the middle of the 2nd century CE - most possible with Pantaenus.

From these passages by Eusebius, it is impossible to determine the starting date of the School. The only 'fact' that can be stated is that there was a School in Alexandria and that it lasted up to at least the end of the 4th century (Van den Broek 1996:205).

\section{The development of the School}

The new religion in the Delta City developed to such an extent that its numbers increased considerably, including members of the other nations living there. This resulted in the founding of the Didaskaleion that was established to promote the ideas of the new religion and to counter the pagan philosophical schools (Fogarty 2004:29). The School began in a humble way as a Catechetical (house) School. At the beginning of its existence, it must have been like a Sunday School, preparing the catechumens for baptism at the house of the teacher. We may refer to it as a place where a '... voluntary, unofficial group of scholars interested in the study and exposition of the Scriptures' gathered (Tripolitis 1985:5).

At the School, the candidates were admitted to learn the Christian faith and to do Biblical Studies to qualify for baptism. Malaty (1995) quotes Rees, who alludes to the School as follows:

The most renowned intellectual institution in the early Christian world was undoubtedly the Catechetical School (Didascaleion) of Alexandria, and its primary concern was the study of the Bible, giving its name to an influential tradition of scriptural interpretation. The preoccupation of this school of exegesis was to discover everywhere the spiritual sense underlying the written word of the Scripture. (p. 10)

Hägg (2006:56) has the same view, namely that the School in its early stages was nothing more than an '... institution of the church to prepare the catechumens for baptism'.

When Eusebius (Hist. Eccl. 6.6.1) first introduced the School of Pantaenus, he implied that catechetical instruction was part of a long-standing tradition of Biblical scholarship. From that, it can be concluded that the School was exactly what its name implied - a Christian school that a teacher most probably had at his private house. The School grew together with the numbers of the followers of the doctrines of Jesus and spread amongst the adherents of Judaism and 
the pagans residing in Alexandria. It was open to all people, regardless of culture, age or background. As the culture of Hellenism still prevailed (McGrath 2013:27), even though the Romans had conquered most of the known world including Egypt, the language of teaching would have been Greek (cf. Fogarty 2004:29).

The Didaskaleion soon evolved onto a full-fledged School '... to meet the needs of a growing Church within a cosmopolitan educated community' (Tripolitis 1985:6). The aim of the School was to instruct learned men in the doctrines and usages of the church, to prepare believers to meet the arguments of the philosophers and to train teachers (cf. Seeley 1914:106). In the words of Barrett (2011:71): 'The early Christian teachers developed a pedagogy which incorporated demanding intellectual thought alongside evangelism.'

It could be asked what the educational standards or qualities of these first teachers were. Fogarty (2004; cf. McGrath 2013:27) stated the following:

The teachers at the school were Greek-trained and the educational principles of the school were thus firmly in Hellenism ... The Greek philosophical training of proselytes was thus a feature from the start, in itself opening the window on gradual departure from the Jewish customs the early believers would have engaged in. (p. 29)

Van den Broek argued in the same vein but more critical though, stating that the teachers in Alexandria, up to Clement, were '... no ecclesiastical officials but laymen' (Van den Broek 1996:200-201).

Although the first impression would be that the School limited itself to theological subjects and Christian philosophy, this was not the case as Science, Mathematics, Greek and Roman literature, Logic and Arts were also taught there (cf. Hist. Eccl. 6.18.3). The teaching was encyclopaedic: At first, students were presented with the whole series of profane sciences. Thereafter, the teachings were more focussed on moral and religious philosophy and finally on Christian theology (Malaty 1995:13). This encyclopaedic method of teaching was an Alexandrian tradition as it also occurred in the Alexandrian pagan and Jewish schools. The question-and-answer method of commentary began here, and 15 centuries before Braille, wood-carving techniques were already used here by blind scholars to read and write (St. Mark's Coptic Church, Melbourne n.d.). The Didaskaleion became the oldest centre for sacred sciences in the history of Christianity. This School was the first to develop a system of Christian theology as well as the allegorical method of Biblical exegesis which better promoted a holistic interpretation of history (Barrett 2011:1).

Malaty (1995:11-13) lists a number of reasons why the School became influential as early as the 2 nd century:

- The Alexandrian Christians were enriched with religious knowledge at an academic level.

- Numerous spiritual and well-known church leaders received their instruction at the School.
- Through its missionary zeal, many foreigners or pagans in Egypt were converted.

- Because of its ecumenical character, many foreign students studied at the School, becoming leaders in their own churches.

- The School was a symbol of the importance of education as a basic element in religion.

- This School was the first in its class to offer the world a systematic theological study.

- The School utilised philosophy to deal with the strong philosophical (pagan) Greek element in Alexandria.

- Despite being a Church School, the Didaskaleion did not interfere in matters and the organisation of the Church of its day.

Duncan (2011:16) states that the School was only loosely attached to the church and at first did not have any attachments to a local bishop (cf. also Osborn 2005:19). Added to this, Vrettos (2001:176) puts the School on the same level as the Greek philosophical schools. As the School, however, gave instruction to catechumens, it seems likely that there would have been some kind of relationship between School and church. Indeed, Malaty (1995:184) records that, during the time of Justus (also called Yostius) (who allegedly headed the School during the last half of the 1st century and the first part of the 2nd), the Bishop (sometimes also referred to as 'Pope') 'took care' of the institution. Also, in the words of Malati as cited in the paragraph above, the School was not a philosophical school, but it used philosophy to deal with the strong philosophical element in Alexandria.

The School flourished in Clement's time, most probably because he accessed the existing libraries more than his predecessors and was well educated in Greek philosophy. Osborn (2005:20) says that, in Clement's time, the School was '... to be seen as a triumph of divine providence in which Christianity and classical culture were brought together'.

The School seemingly became an institutionalised Christian school and the first Christian 'University', instructing the students in a wide range of disciplines (cf. Behr, Louth \& Conomos 2003:48). Duncan (2011:16) suggests that '[i]t was regarded with suspicion by uneducated Christians and with jealousy by ecclesiastics'.

\section{The contributions of Philo and Apollos Philo (20 BCE - 50 CE)}

The writings of Philo (also known as Philo Judaeus or Philo of Alexandria) played a major role in influencing the School. Being a contemporary of Christ as well as a renowned scholar and Jewish philosophical historian and writer - therefore a historian cum philosopher - he lived in Alexandria during the days of the earliest Christians. He devoted himself to Greek and Jewish thought and was often torn between the two traditions. He felt that the Greek philosophers were to some extent influenced by the Torah (cf. Barrett 2011:6). Philo's '... influence upon developing Christian thought is 
as certain as the origin and first beginnings of the Christian gospel in Alexandria, where later these influences were to be so profound ...' (Enslin 1954:216).

The works of Philo seems to have been a fixture in the libraries of both Clement and Origen as both of them were acquainted with it. They used his Biblical interpretations and followed his Platonic ways of thinking. This combination, in which the Platonic underpinnings corroborate their Biblical explorations, may represent the greatest debt of Christianity to Philo (Van den Hoek 1997:79).

The books that Clement wrote in Alexandria show that he had access to the majority of the Philonic treatises. In Clement's last three Stromateis and the other works written after leaving the city, however, the number of citations from Philo dropped off considerably - only a few literal quotations from Philo's Quaestiones in Genesim remained (Van den Hoek 1997:84). Philo was of the view that the Jewish religious views could also be expressed in the language of Greek philosophy (Hägg 2006:60). Following Philo, Clement held that there was only one truth, and '... therefore, any truth to be found in Plato can be no other than the truth that has been revealed in Jesus Christ and in Scripture' (Gonzalez 1984:72).

In Philo, Greek and rabbinical learning met. Whilst Scripture was regarded as the divine authority to furnish evidence of Greek philosophical doctrines, the allegorical method of interpretation was employed to perform this large service (Schaff 1885d:530). He therefore utilised allegorism systematically to bridge the gap between the Old-Testament revelation and Platonic philosophy. According to Philo, all the required wisdom for first Christians was contained in the Pentateuch. He discovered many ideas in the Pentateuch even concealed for Moses - the 'author' of the Pentateuch.

Origen saw to it that this bibliographic tradition continued to spread for when he moved to Caesarea, taking his books and scrolls with him, his collection included writings of Philo. His library was to become the basis of that of Pamphilus and Eusebius, and some of the extant medieval manuscripts of Philo were copies of texts transmitted through the Caesarean library (Van den Hoek 1997:83).

\section{Apollos}

According to Acts 18:24, Apollos was born in Alexandria, most probably during the first half of the 1st century, and he went to Ephesus to proclaim the Word of God. In Ephesus, he met Paul, who afterwards constantly mentioned Apollos as a missionary ( $\mathrm{Tt}$ 3:13) in the same vein as Paul referred to himself and Cephas (Peter's original name). In 1 Corinthians 4:6, Paul classified himself and Apollos as examples of servants of Christ. In 1 Corinthians 16:12, he referred to Apollos as a 'brother'.

This Apollos allegedly made a strong contribution to the establishing of the followers of Jesus in Alexandria and also acted as a precursor to the formation of the School. Schaff (1885c:567) supplies reasons why the rise of the School can be treated as an outcrop of the learning and piety of Apollos and why he was regarded as a major influence on the School:

- The character and words of 'this brilliant Alexandrian' had a big influence on converts in Alexandria.

- The frequent way in which the Alexandrians referred to Apollos, as Luke did in Acts 18:24, confirmed Schaff's suspicion that they always had his good example in mind.

- As Schaff is convinced that the School was established in Alexandria in apostolic times, he thinks that Apollos could have been part of it. A 'good reason' for Schaff to postulate that Apollos was part and parcel of establishing the School comes from Mark (an evangelist, and according to Eusebius, the first 'head' of the School): If Mark was credited with a connection with Alexandria, even though there was no Scriptural evidence, then Apollos should likewise be credited because he has one text in his favour, namely Acts 18:26. Schaff quotes this text as evidence from which he interpreted that Aquila and Priscilla instructed Apollos that he should found catechetical schools for other followers of Jesus.

- The fact that Clement was silent about Apollos was, according to Schaff (1985c:567), ' $\ldots$ an objection quite as fatal to the claims of St. Mark'.

- The unanimity of the Alexandrians, from Pantaenus onward, to assign to Paul the authorship of the Epistle to the Hebrews whilst it was so much debated elsewhere suggests that they had early evidence (it could be a tradition) on this point. Apollos could have been the source. Clement's testimony about Luke convinced Schaff that Apollos had testified to the Alexandrians that Paul was the author.

- Nothing is known about Apollos after 64 CE. Schaff is convinced that he moved back to Alexandria, bearing the Epistle to Titus and a copy of the Epistle to the Hebrews, written the previous year.

Schaff states that the genius left by Apollos was to revive the Delta City and to create a succession of scholars to arise like him, '... eloquent men, and mighty in the Scriptures' (Schaff 1885a:370). This is worth mentioning, just as worthy as all the other speculations about the heads of the School. Yet it all contributes to the fact that there were people in Alexandria who were serious about teaching and converting the inhabitants of the city to become followers of Jesus Christ's teachings.

\section{Alexandria and Antioch}

The School at Alexandria and the School of Antioch in Syria - founded during the last half of the 3rd century - were the two major centres for the study of theology and Biblical exegesis in the Early Church. Whereas the Didaskaleion utilised the allegorical method for interpretation the Scriptures, complemented by a Christology that emphasised a union between man and God, the School of Antioch championed a more literal (occasionally typological) or 
historical exegesis and a Christology depicting the distinction between man and God in the person of Jesus (McGrath 2013:32; cf. Coptic Orthodox Church Network 2012).

As the debate on Christology seemed to be somewhat technical, it was an important marker of the increasing importance of these two cities as they were both centres of theological reflection and places of ecclesiastical leadership (cf. McGrath 2013:32). At the end of the 4th century, both cities had gained imperial recognition and privilege whilst their bishops were able to voice their views on the location of spiritual authority within the church. According to Schaff (1885b), Alexandria remained the greatest:

The reader will remember the rise and rapid development of the great Alexandrian school, and the predominance which was imparted to it by the genius of the illustrious Clement. But in Origen, his pupil, who succeeded him at the surprising age of eighteen, a new sun was to rise upon its noontide. Truly was Alexandria 'the mother and mistress of churches' in the benign sense of a nurse and instructress of Christendom, not its arrogant and usurping imperatrix. (p. 545).

\section{Teachings of the School}

As has been mentioned, the students (including the catechumens) at the Didaskaleion did not only study theology or theological subjects but also profane subjects. It has also been mentioned that the teachings were encyclopaedic: The students were first presented with the whole series of profane sciences, and then, the teachings were more focussed on moral and religious philosophy and, finally, on Christian theology. According to Malaty (1994:13), and based on the main works of Clement, the School apparently presented three main courses, namely: (1) a special course for non-Christians, which introduced them to principles of Christianity, (2) a course on Christian morals and (3) an advanced course on divine wisdom and sufficient knowledge for the spiritual Christian.

The School did not only teach the students how to become Christians but also showed it to them in practice. The students were taught how to practise prayer, how to fast and how to practise different ways of asceticism. Besides purity and integrity, they were also encouraged to observe the celibacy (Malaty 1994:13).

\section{Forms of teaching in the School}

Three forms of teaching were prominent in the School, namely allegorism, philosophy and gnosis [the teaching of knowledge].

\section{Allegorism}

The roots of allegorism lay in the Jewish rabbinical treatment of Old-Testament texts as well as in the Greek philosophy of Alexandria. Philo was a greater supporter of mystical and allegorical interpretations than of literal meaning. He was really good at allegory and was 'tagged' by some scholars as the master, even inventor (cf. Schaff 1885d:530) of allegorism in Alexandria (cf. McGrath 2013:27). Barrett (2011) puts forward the following conviction:

Philo's endorsement of allegorical interpretation and intellectual study initiated a trend of historiography which would influence the teachings of Paul as well as pervade the catechetical school of Clement and Origen. (p. 7)

Although this method was in use before Clement and Origen, it was through them that it became firmly established in the Didaskaleion and also in the church. The scholars at the Didaskaleion believed that the allegorical interpretation of the Scriptures simultaneously hides and reveals the truth: It hides the truth from the uninstructed, who would not be able to understand it, but it reveals the truth to the believer. Clement is considered to be the first Christian writer to use this method, alluding to the Bible as a book full of hidden meanings and encouraging the (faithful) reader to search and discover the truth. This made Alexandria the origin of allegorism (cf. Schaff 1885d:530).

According to Duncan (2011:17), allegorism was used within a set of exegetical principles:

- When using allegorical interpretation, the interpreter has to keep with the primary meaning of the text unless the text itself contradicts the dignity and character of God.

- Each text has to be interpreted in the light of the rest of Scripture - thus within its context.

It is said that an allegorical interpretation better promoted a holistic interpretation of history (Barrett 2011:1).

\section{Philosophy}

This sub-heading must be read in the light of what has been stated under sub-heading 'Religious and philosophical background'. Justin Martyr (100-165 CE, in his Dial. 2.1-2) spoke of Christianity as a philosophy (cf. Löhr 2010:176). He was correct because in his time the term only referred to a 'set of ideas' and not to philosophy as understood today (McGrath 2013:22). In his time, philosophy was both a way of thinking and a way of living, being enacted by different philosophies such as the Stoics, Platonists, Peripatetics and Epicureans (Löhr 2010:176). Barrett (2011) refers to the acceptance of philosophy by the followers of Jesus in the following way:

Christianity entered as an innovative character on the already established academic scene. The presence of Judaism in Alexandria as Christianity began to assimilate into the culture provoked Christian attention to philosophical development. (p. 6)

In the Empire, the most important influence of philosophy came from the Greeks and not the Romans. In the words of Malaty (1995:153-154): 'Roman power and Roman law controlled the military, political, social, and economic life of the empire; Greek thinking controlled the minds of men.'

Athenagoras, the teacher of Pantaenus, can be considered the first known Christian who had a tendency towards philosophy. As the Didaskaleion made use of encyclopaedic teaching, there was a clear interest in science and philosophy. 
The teachers at the School believed that the study of philosophy and rhetoric were the two main ways to complete education. Duncan (2011:16) refers to their way of dealing with philosophy by stating that ' $[i] \mathrm{t}$ challenged existing philosophical systems yet recognised aspects of truth in them: it was sympathetic to pagan systems'.

Barrett (2011:82) pointed out that 'Philo initiated the manner of defending Christianity within paradigms of Greek philosophy by attempting to wed Judaism with Greek philosophy'. The School followed Philo by explaining Christian beliefs in the light of Greek philosophy (Hatch 1957:129). In doing so, they wanted to demonstrate the similarity between the best of Hellenistic thought and their own sophisticated versions of the Christian message (Olson 1999:55). In their evangelical efforts, the early Christians blended their Christian life and worldview with Platonism and Stoicism that qualified mainstream Greek philosophy. Stoicism was, however, soon to fade away in Alexandria and was replaced by Neo-Platonism, which was a mixture of the philosophies of Plato and Aristotle with the mysticism of Pythagoras added to it (Duncan 2011:16).

Macleod (2002:148) says that Platonic thoughts coincided with the development of Christian theology and that there were areas of contact and commonality between the two ideologies. Greek philosophy was implemented, and it '... contended strongly for the spiritual nature of the reality behind and beneath all visible things' (Olson 1999:56). As the Platonists were dismissive of the books of the Bible because of the 'poor Greek' in which it was written, the School undertook with their writings the task of reconciling the books of the Bible with Hellenism, particularly the philosophy of Plato. Added to this, they used philosophy as a weapon against Gnosticism.

Plato and Aristotle discussed theories regarding the Greek polis (city). Barrett (2011) phrases this discussion as follows:

The goal of the Greek polis was the common good, which was achieved through shared responsibilities. The Alexandrian school reflects the ideal of the Greek polis as educational responsibilities were shared between Christian and philosophical ideas. (p. 7)

Though Christianity was still in its early days, philosophy offered an expansive heritage which Clement and Origen used as foundation for their theological viewpoint and spiritual discipleship (cf. Barrett 2011:98). The writings of Plato (429-347 BCE), one of the greatest philosophers in Western history, especially influenced Clement to have a high regard for philosophy. Plato followed his teacher Socrates (470-399 BCE) who devoted his life to philosophical study (Cantor 2003:18-19). Socrates described self-knowledge as a more pertinent issue than empirical inquiry. This means that people should explain why they do something before the think of the process of how to do it. This made Socrates hesitant about putting any of his teachings in writing or bringing it to words in any way. Plato differed from Socrates in that he wrote extensively.
According to Clement, much of the Christian doctrine was dependent on Plato's philosophy (cf. Barrett 2011:25). In his teachings, Clement acknowledged Plato's four 'cardinal virtues', which he included in his Christian philosophy: Wisdom, courage, self-control, and justice (also cohesive with Philonic thought) (cf. Barrett 2011:26).

Clement defended Christianity against people who thought that this 'new religion' was only for the ignorant and the poor. He was instrumental in helping the church to shape its character through his mutual interactions with faith and philosophy. He believed that Christianity and philosophy were mutually compatible: 'Clement drew heavily on the historical influences of Plato and classical Greek ideas to promote cohesion between Christianity and philosophy' (Barrett 2011:15).

According to Hägg (2006:218), Clement did not only want to offer Christianity as the fulfilment of philosophy but also encouraged Christians to find the truth in philosophy because (according to Behr et al. 2003:49) true philosophy was seen as the love of truth and a striving to know the true God. Knowledge of the true God was then a way to contemplate the original harmony of the cosmos (cf. MacCulloch 2009:124).

Clement held that the Greeks received philosophy in the same way that the Jews had received the Law from God. Both of them were precursors of the ultimate truth being revealed in Christ. However, Christianity was the true philosophy that fulfilled Greek philosophy. He held that '... the complete Christian is marked by knowledge, perfection, progress, and prayer' (cf. Osborn 2005:269). His work made history by shifting and merging compatibility between Greek philosophy and Christianity. The term Logos is represented in both Greek philosophy and Christianity. Greek philosophy saw the logos as the '... rational order of the universe, and immanent natural law, a life-giving force hidden in things' (Stark 2007:322). His exposition of the divine Logos '... formed the basis for Christological thought to follow' (Barrett 2011:31).

The most influential Platonic belief on early Christian thought was the teaching on the nature of God (Lynch 2010:35). When the Platonists refer to 'the One', it meant the origin of everything. For Plato, 'the One' was '... beyond description and beyond human understanding' (Lynch 2010:35). Christianity could easily be compared with that. Just as God had a Mediator, philosophy also had one, called the logos [word], to interact with humanity. Plato also believed in a triad at the centre of the universe. Clement made ample use of these views (cf. Barrett 2011:24).

The early Christians shared with the philosophers the belief in monotheism - in contrast to the pagan religions. As polytheism had become an embarrassment in many pagan circles, the monotheism of Christianity appealed to the intellect of the people (Stark 2007:322). Olson (1999) stated it thus:

Most educated and thoughtful people of the empire considered 'true doctrine' to include belief in a single deity whose exact 
identity is beyond human knowledge but who shaped the universe and rules over it as a kind of benevolent and just despot. (p. 56)

Barrett (2011:82) added to this: 'From this point of agreement among educated people, Greek and Christian, philosophical and theological conversations blended as the concept of God became the subject of cosmological discussion.'

Philosophy slowly but surely started to soak Alexandrian Christianity to the point where faith and philosophy became intertwined.

\section{Gnosis}

There was a difference between the Gnostic sects in Alexandria and the gnosis that the School applied. Best here is to refer to Clement's use of the term. In his Stromateis, he referred to a Christian Gnostic as an orthodox Christian who received the divine gnosis [knowledge] from the Holy Spirit, by illumination through Christ (the Logos) within the church's traditional beliefs. Clement held that every Christian was a true Gnostic, perfected in knowledge, thus stating that faith was the criterion of knowledge (cf. Strom. 2.9). Clement propagated a rational faith. He was in favour of studying secular sciences and philosophy. If Christian were learned, they would be able to distinguish between truth and lies, and they would guard Christian faith against its enemies. He stated that one's perspective can be corrupted if lacking true reason (Barrett 2011:87).

Clement regarded Christ as the source of gnosis by the grace of the Father, granting one his knowledge through baptism and through reading the Scriptures. He regarded gnosis as the principle and author of every action one has to take in order to conform to the Logos. According to him, the true Gnostic has a desire for knowledge, struggles to practise goodness and makes effort with prayer, witnessing to God daily (as a martyr) and never fears death. This person had to know, see and possess God. This assumption made one almost equal to the angels.

Contrary to the Gnostics (as his Stromateis was written against the Gnostics), Clement held that '... gnosis is often used as an equivalent of God's message in Scripture, also called a mystery' (Strom. 5.10; cf. Hägg 2006:151). He therefore interpreted gnosis to be a mystery of God and even as the divine Logos. Faith was the necessary foundation for gnosis. Thus, in order to have gnosis, one first had to believe - to have faith. Faith was essential in the sense that it was a first step to understand the divine mysteries (cf. Sellers 1940:13), penetrating beyond the literal surface to the symbolic. To get gnosis of God, one had to love God. For Clement, gnosis was the '... door to a higher form of Christian spiritual life' (Strom. 8.1; cf. MacCulloch 2009:148).

Clement's use of gnosis evoked suspicion amongst Christians (Hägg 2006:32). According to Clement, a true Gnostic is '... a person of wisdom who lives off the mind and shuns the lower life of the pursuit of bodily desires and pleasures ... becoming Godlike in virtue and wisdom' (Quis dives Salvetur? 12; cf. Olson 1999:88). A true Gnostic would develop as many attributes of God as possible. This could be the reason why Clement devoted much of his writing to gnosis to contrast it with Gnosticism's use of the word. Clement devoted his Stromateis to his epistemology - a philosophical understanding of knowledge (cf. Barrett 2011:28).

Clement thus regarded faith as the foundation for the two kinds of knowledge in his writings - spiritual knowledge (referring to the truth found in Christianity) and logical knowledge (addressing reason). For him, faith was the foundation and necessity to find knowledge in God. In both of these kinds of knowledge, faith and reason would function cohesively: Faith would be the starting point with reason building on it. In Clement's words, 'Christians who are content with faith, and do not use reason to build upon it, are again like a child who is forever content with milk' (Strom. 6.14; cf. Gonzalez 1984:73).

Despite all of this, Clement maintained that God can only be known through the mediation of the Son (cf. Hägg 2006):

In knowing God, Clement emphasized developing a conception of God rather than attempting to describe God. Attempting a description of God, Clement employed negative language to describe who God is not. This method is termed via negative. (p. 212)

\section{Characteristics of the School}

Barrett (2011) makes a general remark concerning the characteristics of the School:

The Alexandrian school characterized a theological paradigm, best represented in the work of Clement and Origen. Alexandrian theology maintained an apologetic tradition that Christianity was a revealed philosophy, and from this mentality the catechetical school was derived. (p. 4)

Seven characteristics of the School were prominent and will be discussed here. Malaty (1995:15-29) names the first six of them. The words of Malaty (1995) serve as a good introduction to these characteristics:

Pope Anianius, who was ordained by St. Mark himself, took care of the School, and all who joined it renounced the world to devote their lives to the worship and service of God, living in true love and spiritual peace; there was no rich nor poor among them, for the rich gave their money to the poor, to be rich in God. They ate once a day at sunset, both men and women alike in this respect. We can say that the two most important characteristics of the School were the combination of study with spiritual life, such as prayer, fasting and almsgiving. It was open and men and women were co-admitted to the School. (pp. 183-184)

\section{Deification}

Deification was the core of Alexandrian theology. With the term 'deification', the Alexandrians had in mind the renewal of human nature as a whole. This renewal would include the discarding of the corrupt human nature in order to partake in the characteristics of Jesus Christ. They founded their view on 
two Scriptures, namely 2 Peter 1:4 (partaking in Jesus' divine nature) and Colossians 3:10 (the renewal of knowledge in the image of the Creator). Clement makes two references in that context:

- In Quis Dives Salvetur 37, he referred to Jesus: 'For this he came down, for this he assumed human nature, for this he willingly endured the suffering of man, that by being reduced to the measure of our weakness he might raise us to the measure of his power.'

- In Protrepticus 1.8.4, he stated: 'The Word of God became man just that you may learn from a Man how it may be that man should become godly.'

The Holy Spirit was seen as the One who was to renew human nature to come in close unity with the Father and the Son.

\section{Oneness of life}

The belief of the School was to integrate the students' study of religion, philosophy and science with their church life as well as their daily life. The Christian life should be a response to divine revelation. This culminated in the heads and students being true worshippers, ascetics and preachers.

\section{Soteriological theology}

The School did not present God as a mere idea to believe in but as a Reality - the Saviour who is known through his redeeming deeds to mankind. This was the basic principle of the Alexandrian theology. The School advocated a close relationship between (the acquisition of) theological knowledge and salvation.

\section{Penance and repentance}

Alexandrian theology was soteriological, and therefore, penance and repentance were preconditions. Origen, in his Second Homily to Leviticus, summarised the seven ways for sins to be forgiven. They were baptism, martyrdom, almsgiving, forgiving your neighbour's sins, restoring a sinner, abundance of charity and penance - having real remorse about one's sins and confessing one's sins to a priest of the Lord, asking him for a remedy.

\section{Theological terms and definitions}

Being ensconced in Hellenism, the School mostly utilised Greek philosophical terms to explain Christian doctrines and to deal with the philosophers and heretics around them. These, however, did not define their theological terminology whatsoever.

\section{Ecumenical spirit}

The School practised ecumenism by attracting quite a few foreign students to enrol with them. The heads of the School set the example by being actively involved in the universal church, like Origen who visited Rome, Caesarea, Arabia and Tyre. Also, at the ecumenical councils, the Alexandrian theologians played a pivotal role.

El-Abbadi (1993:70-71) mentioned a letter from a wellconnected Roman Christian to Christians in Alexandria, indicating the role played by the Alexandrian School as a link between the Egyptian Christians and those elsewhere in the world. That letter referred to 'Papa Maximus', the bishop of Alexandria and therefore signified, according to El-Abbadi, the recognition by Christians elsewhere of the bishop's status as head of Egypt's Christians.

\section{Apology}

Apology formed an implicit part of most of the teachings at the Didaskaleion. As Christianity developed in Alexandria, so did all the other religions, cults and philosophies. The champions of the newly found religion had to defend this religion against all the others, and this developed into an early Christian apology. The early apologists in Alexandria may be referred to as the Egyptian Christian apologists (cf. Fogarty 2004:124). Apology prevailed from the late 1st century onwards until at least the 5th century. The reasons why the apologists were so important were the following (cf. Fogarty 2004:124):

- They held a mirror to the conflict on various systems of belief.

- It was the first real attempt to systematise the Christian religion. This helped much with the development of a theology.

- Their writings supplemented the reading of Scriptures.

- In this way, they contributed to the spread of the Christian religion - for both believers and non-believers.

As Christianity was still in its infancy, these writers tried to set things straight about the new religion in order to display the real character and conduct of the adherents to this religion. They also tried to wipe out the prejudice of the Emperors which led to the violent persecutions of the adherents (Schaff 1885d:496). They wrote in such a way that their readers would discover that theirs was a philosophy as well as a divine revelation. They argued against polytheism and showed the disastrous effects it had on morality.

Aristides and Quadratus were the first apologists. Whilst the latter's work is lost in total, the former's Apology was discovered in 1889, dating back to $125 \mathrm{CE}$ as Aristides presented his Apology to Emperor Hadrian (cf. Schaff 1885d:499). In the latter part of the 1st century, Athenagoras wrote two apologetic works, called Legatio [Pleading (for Christians)] and De Resurrectione [About the resurrection from the dead]. Justin Martyr, who reached his zenith during the middle of the 2nd century, headed the group of apologists whose works are extant, like Tatian, Melito, Theophilus and the author of the Epistle to Diognetus - all of them wrote in Greek. There were also Latin apologists during the 2nd century, like Tertullian, Minucius Felix, Arnobius and Lactantius (Schaff 1885d:496). 
Clement and Origen were two 2nd and 3rd century apologists whose '... contributions in the formulation of early Christianity were of a scope and depth seldom, if ever, matched by any of their successors' (Fogarty 2004:124). Clement wrote apologetic works against Gnostics like Valentinus, Basilides and Theodotus. Origen's Contra Celsum was an outstanding apologetic work though it did not have much influence on the church of his time (cf. Coptic Orthodox Church Network 2012).

A century after Clement and Origen, Augustine of Hippo (in North Africa) also made valuable contributions. In his writings, a change from the first two apologists is visible because his writings were more directed at Roman audiences and concerns, surely far removed from the distinctly Hellenistic philosophical world in which the Egyptians had worked. Augustine's writings therefore depicted the transition occurring in Christianity away from Egypt and Africa towards the Roman and Western world.

The apologists wrote against sharp criticism, '... from sporadic persecution to quite spurious claims by pagans that the Christians engaged in immoral acts such as promiscuity, and even cannibalism, at their secret meetings' (Fogarty 2004:124). Some of the apologists' writings (especially Tertullian) sometimes contained heated and sarcastic remarks.

\section{The demise of the Didaskaleion}

Van den Broek (1996) recorded the demise of the School as follows:

After Didymus' death [398 CE], the School ceased to exist. Bishop Theophilus (385-412), the declared enemy of paganism and Greek culture, no longer accepted independent theological speculation. From then on, only the bishop was held to be competent in matters of doctrine, he decided what kind of theology had to be taught in his church. (p. 205)

Although Van den Broek might have been justified in recording the cessation of the School's activities after Didymus, Philip Sidetes named a successor, namely Rhodon, as stated in the following article (see comment 2, above). Rhodon, however, moved the School from Alexandria to Side.

\section{The School today}

The Theological College of the Catechetical School of Alexandria was re-established in 1893. The new School currently has campuses in Alexandria, Cairo, New Jersey and Los Angeles where Coptic priests-to-be and other qualified men and women are taught, amongst other subjects, Christian theology, history and Coptic language and art - including chanting, music, iconography and tapestry (St. Mark's Coptic Church, Melbourne n.d.).

\section{Conclusion}

As the earliest Christians settled in Alexandria, most probably in the second half of the 1st century, they were confronted by a vast array of other religions, cults and philosophies. Mark was already there doing missionary work during the fifth decade CE. They, therefore, did not present any Fremdkörper also because of the presence of Judaism in the city and because of Apollos who was already there preaching the gospel. This city was renowned for her academic excellence in the Roman Empire with schools or universities like the Musaion, the Serapium and the Sebastion. The adherents to this new religion then also started with what can be called a house school where catechumens were prepared for baptism. Because of the missionary character of this religion, pagans were soon permitted to enter the School, and the curriculum was soon extended with subjects like Science, Mathematics, Greek and Roman literature, Logic and Arts. In this way, the Didaskaleion grew to form part of a network of schools or universities in Alexandria.

Being influenced by philosophers like Philo Judaeus and Plato, three forms of teaching were prominent in the School, namely allegorism, philosophy and gnosis. Coupled with the apologetic character displayed in the writings of, especially, Clement and Origen, the Didaskaleion was (almost) on the same level as the mentioned schools.

At first, the School operated rather independently from the church in the sense that a bishop was not in charge of the School - the first heads were merely laymen. After the death of Didymus, the School ceased to exist in Alexandria. This was the time when the bishops took over the responsibility in matters of doctrine for the Christians in the Delta City.

In a follow-up article to this one, the heads of the School will be discussed in detail.

\section{Acknowledgements Competing interests}

The author declares that he has no financial or personal relationships which may have inappropriately influenced him in writing this article.

\section{References}

Barrett, N.C., 2011, 'The Alexandrian Catechetical School of Clement and Origen as a postmodern model for the contemporary church and theological academy', MA dissertation, Department of Religion, Hardin-Simmons University.

Behr, J., Louth, A. \& Conomos, D. (eds.), 2003, Abba: The tradition of Orthodoxy in the West, St Vladimir's Seminary Press, Crestwood.

Cantor, N.F., 2003, Antiquity: From the birth of Sumerian civilization to the fall of the Roman Empire, Harper Perennial, New York.

Coptic Orthodox Church Network, 2012, viewed 25 August 2014, from http:// copticchurch.net/

Duncan, G., 2011, Early church up to Augustine, CHI114/CHS 110 class notes, University of Pretoria.

El-Abbadi, M., 1993, 'Alexandria: Thousand year capital of Egypt', in G. Steen (ed.) Alexandria. The site and the history, pp. 35-82, New York University Press, New York.

Enslin, M.S., 1954, 'A gentleman among the fathers', The Harvard Theological Review 47(4), 213-241. http://dx.doi.org/10.1017/S0017816000024962

Fogarty, M.E., 2004, 'Egyptian Christianity: An historical examination of the belie systems prevalent in Alexandria C.100 B.C.E - 400 C.E', M Phil dissertation, Department of Ancient Near Eastern Studies, University of Stellenbosch.

Gonzalez, J.L., 1984, The story of Christianity, vol 1: The early church to the dawn of the Reformation, Harper, San Francisco. 
Grafton, A. \& Williams, M., 2006, Christianity and the transformation of the book, Harvard University Press, Cambridge.

Hägg, H.F., 2006, Clement of Alexandria and the beginnings of Christian apophaticism Oxford University Press, New York. http://dx.doi.org/10.1093/0199288089.001.0001

Hatch, E., 1957, The influence of Greek ideas on Christianity, Harper \& Brothers Publishers, New York.

Isichei, E., 1995, A history of Christianity in Africa, William B. Eerdmans Publishing Company, Grand Rapids.

Löhr, W., 2010, 'Christianity as philosophy: Problems and perspectives of an ancient intellectual project', Vigiliae Christianae 64, 160-188. http://dx.doi. org/10.1163/157007209X453331

Lynch, J.H., 2010, Early Christianity: A brief history, Oxford University Press, New York. MacCulloch, D., 2009, Christianity: The first three thousand years, Viking, New York.

Macleod, R. (ed.), 2002, The library of Alexandria: Centre of learning in the ancient world, IB Tauris Publishers, New York.

Malaty, T.Y., 1995, Lectures in patrology: The school of Alexandria. Book one: Before Origen, St. Mark's Coptic Orthodox Church, Jersey City.

McGrath, A.E., 2013, Christian history: An introduction, Wiley-Blackwell, Chichester.

Olson, R., 1999, The story of Christian theology: Twenty centuries of tradition and reform, IVP Academic, Grove.

Osborn, E., 2005, Clement of Alexandria, Cambridge University Press, New York.

Prinzivalli, E., 2003, 'La metamorfosi della scuola alessandrina da Eracla a Didimo', in L. Perrone (ed.), Origeniana Octava, pp. 911-937, Peeters, Leuven.

Ramelli, I.L.E., 2009, 'Origen, Bardaișan, and the origin of universal salvation', Harvard Theological Review 102(2),135-168. http://dx.doi.org/10.1017/S0017816009000728

Schaff, P. (ed.), 1885a, Ante-Nicene fathers, vol. 2: Fathers of the second century: Hermas, Tatian, Athenagoras, Theophilus, and Clement of Alexandria (Entire) Christian Classics Ethereal Library, Grand Rapids.

Schaff, P. (ed.), 1885b, Ante-Nicene fathers, vol. 4: Fathers of the third century: Tertullian Part IV; Minucius Felix; Commodian; Origen, Christian Classics Ethereal Library, Grand Rapids.
Schaff, P. (ed.), 1885c, Ante-Nicene fathers, vol. 6: Gregory Thaumaturgus; Dinoysius the Great; Julius Africanus; Anatolius and minor writers; Methodius; Arnobius, Christian Classics Ethereal Library, Grand Rapids.

Schaff, P. (ed.), 1885d, Ante-Nicene fathers, vol. 9: Recently discovered additions to early Christian literature; Commentaries of Origen, Christian Classics Ethereal Library, Grand Rapids.

Scholten, C., 1995, 'Die alexandrinische Katechetenschule', Jahrbuch für Antike und Christentum 38, 16-37.

Seeley, L., 1914, History of education, American Book Company, New York.

Sellers, R.V., 1940, Two ancient Christologies: A study in the Christological thought of the schools of Alexandria and Antioch in the early history of Christian doctrine, Society for Promoting Christian Knowledge, Northumberland.

St. Mark's Coptic Church, Melbourne, n.d., viewed 25 August 2012, from http://www. stmarkscopticchurchmelbourne.com/history/54-the-catechetical-school-of alexandria.htm

Stark, R., 2007, Discovering God: The origins of the great religions and the evolution of belief, Harper One, New York.

Tloka, J., 2006, Griechische Christen, Christliche Griechen, Mohr Siebeck, Tübingen.

Tripolitis, A., 1985, Origen: A critical reading, Peter Lang, New York.

Van den Broek, R., 1995, 'The Christian "school" of Alexandria in the second and third centuries', in J.W. Drijvers \& A.A. MacDonald (eds.), Centres of learning: Learning and location in pre-modern Europe and the Near East, pp. 39-47, EJ Brill, Leiden. http://dx.doi.org/10.1163/9789004247154_005

Van den Broek, R., 1996, Studies in gnosticism and Alexandrian Christianity, EJ Brill, Leiden. (Nag Hammadi and Manichaean Studies 39).

Van den Hoek, A., 1997, 'The "catechetical" school of early Christian Alexandria and its Philonic heritage', Harvard Theological Review 90(1), 59-87. http://dx.doi. org/10.1017/S0017816000006180

Vrettos, T., 2001, Alexandria: City of the Western mind, The Free Press, New York.

Wilken, R.L., 1979, 'Kollegien, Philosophenschulen und Theologie', in W.A. Meeks (ed.), Zur Soziologie des Urchristentums, pp. 165-193, Kaiser, Munich. 